\title{
An integrated analysis of gravity and well data for deep-seated structural interpretation: a case study, from Ras Budran oil field, Gulf of Suez, Egypt
}

\author{
A. A. Azab' - M. A. Ramadan ${ }^{1}$ - M. Z. El-sawy ${ }^{1}$
}

Received: 11 October 2017 / Accepted: 4 July 2018 / Published online: 19 July 2018

(c) The Author(s) 2018

\begin{abstract}
A combined gravity and well-logging data study was put forward to explore the subsurface structural configurations in Ras Budran oil field area. At first, all available open-hole logging data in the form of porosity tools (density, sonic, and neutron), gamma-ray and resistivity logs (shallow and deep) beside the composite logs were used in determining the lithology and dividing it into three different groups, namely, pre-evaporites, evaporites, and post-evaporites. In addition, the Bouguer anomaly map had been integrated with the available borehole information for interpreting the deep-seated structures which not imaged by surface seismic reflection data. The structural analysis is based essentially on the strip off technique to minimize the ambiguity in the deep gravity data interpretation. This was accomplished through computing the gravity effect of each sedimentary layer of a known density and geometry. Several stages of deep gravity interpretation were done by calculating and removing the gravity effect of the overlying sedimentary section above the stripping datum. The process led to localization and enhancement of the gravity anomalies which give more details about the deep structures/sources. In general, the study reveals that the negative gravity effect of the thick surficial layer (post-evaporite sediments) over all the area is strong enough and superior. The positive gravity effect of the shallow evaporites seriously distorts the negative ones of the pre-Miocene clastics. The gravity effect of the deep sources including the Rudeis-Nubian interval generates the most relevant contribution to the strip off gravity, especially in the southern portion. The stripped gravity of the pre-evaporite strata is distinguished by two local lows in the southern part that could be interpreted in terms of gravity as two local troughs on the basement surface. The density models exhibit the presence of an anticlinal structure correlated with Ras Budran oil field, which is surrounded by two fill-sediment grabens from south direction. This confirm that the near-surface bodies are the most affective to obtain a good fit between the observed and calculated profiles.
\end{abstract}

Keywords Gravity stripping $\cdot$ Well logging $\cdot$ Gulf of Suez $\cdot$ Ras Budran $\cdot$ Bouguer map

\section{Introduction}

The Gulf of Suez area is generally characterized by a thick sedimentary section that can be subdivided into three different rock units from top to base; the post-Miocene/postrift succession of the Pliocene-Holocene age, syn-rift succession of the Miocene-Oligocene age, and pre-Miocene/ pre-rift of the Eocene-Paleozoic age. The three packages are greatly varying in lithology, depositional environment,

M. Z. El-sawy

marwa_epri@yahoo.com

1 Egyptian Petroleum Research Institute, P.O. 11727, 1 Ahmed Alzomor St., Alzohour District, Nasr city, Cairo, Egypt hydrocarbon accumulations, as well as its thickness and areal distribution. The previous works indicate that the southern portion of the gulf is dominated by tilted-basement blocks and NE-SW offset linear highs; meanwhile, the central and northern parts of the gulf comprise several elongated depositional basins. Numerous geophysical studies were carried out to detect the most probable locations for the structural and stratigraphic traps. The deep structural highs on top of basement surface are focal points to determine the oil accumulations within the sedimentary basins. The pre-Miocene uplifts were put into focus as the main sources of potentiality in the Gulf of Suez. Unfortunately, seismic has no efficiency to well explore/reach such deep-seated structures. Contrary, it is found that gravity interpretation by stripping is more effective to reveal the 
deeper constituents of interest. It calculates the gravity effect of shallow sources/structures of known densities and geometries, where the removal of such shallow gravity effects may lead to show the gravity effects resulted from the deep-seated disturbances in the subsurface. Therefore, the gravity stripping is more accurate and reliable than the mathematical filtering or separation methods, since the filtered maps contain false anomalies with inaccurate amplitudes.

The Ras Budraan (RB)-oil field locates in the central province of the Gulf of Suez, at $4 \mathrm{~km}$ apart from the Sinai coast. It is situated to the east of October oil field and northern of Shob Al oil field, at about $13 \mathrm{~km}$ south of Abu Zenima city and $15 \mathrm{~km}$ north of Abu Rudeis. The area under investigation is located between latitudes $28^{\circ} 56^{\prime} \mathrm{N}-29^{\circ} 04^{\prime}$ and longitudes $33^{\circ} 05^{\prime} \mathrm{N}-33^{\circ} 12^{\prime} \mathrm{N}$ (Fig. 1 ).

The objective of the study is to overcome the lack of seismic imaging beneath the thick Miocene evaporites. The analyses focus attention on the deep structural configurations at the pre-Miocene level and on basement surface. The plan is to re-interpret the gravity data supported by well-logging information to quickly grasp the structural setup. The approach of interpretation is to remove the gravity effect at different levels of the post-evaporites and Miocene evaporites to identify the deep prospects. Certain emphasis was put on the pre-Miocene uplifts which considered as focal point for further prospecting. The available data used in this interpretation are the Bouguer gravity map as a main source of information, scale of 1:100,000, and contour interval $1 \mathrm{mGal}$. The map was prepared by the Pan American oil company (1986) and made available by the Egyptian General Petroleum Corporation EGPC.
Besides composite well logs and density logs for a number of drilled wells in the study area, under auspices of Anglo Egyptian oil field Ltd. which was granted the exploration license in the study area since 1978.

Reviewing the drilling information in the study area indicates that the RB-oil field is correlated with a structural uplift in the subsurface. The anticlinal feature strikes nearly in an NE-SW direction and broken into several parallel panels by a set of NW-SE-trending faults. The drilled wells hit the uplifted block at early Miocene level. From the other side, the previous seismic studies in the study area indicate that the capability of the seismic method to identify the deep horizons beneath the evaporite rocks is nearly impossible. Due to the strong shielding effect of the evaporite beds with respect to seismic energy, no coherent horizons could be confidently seen or mapped below the base of evaporite rocks. Likewise, the potential field data, either magnetic or gravity, show no signals that can be definitely correlated with the anticlinal feature of the RB-oil field. The Bouguer gravity map of the study area does not clearly reflect the local uplift that might be hidden in the subsurface. This seems to be logic, since local structures that might be present at the flanks of the major geosynclines are overprinted by the larger features caused by the regional structural trend. However, why the anticlinal structure of RB-oil field not correlated with gravity anomalies?

At first, we tried to use two different filtering processes; regional-residual separation, and second vertical derivative, as preview methods to explore the deep sources in the study area. However, the anticlinal feature of the RBoil field seems to poorly defined by these two filters. The filtered maps show that no gravity anomalies correspond

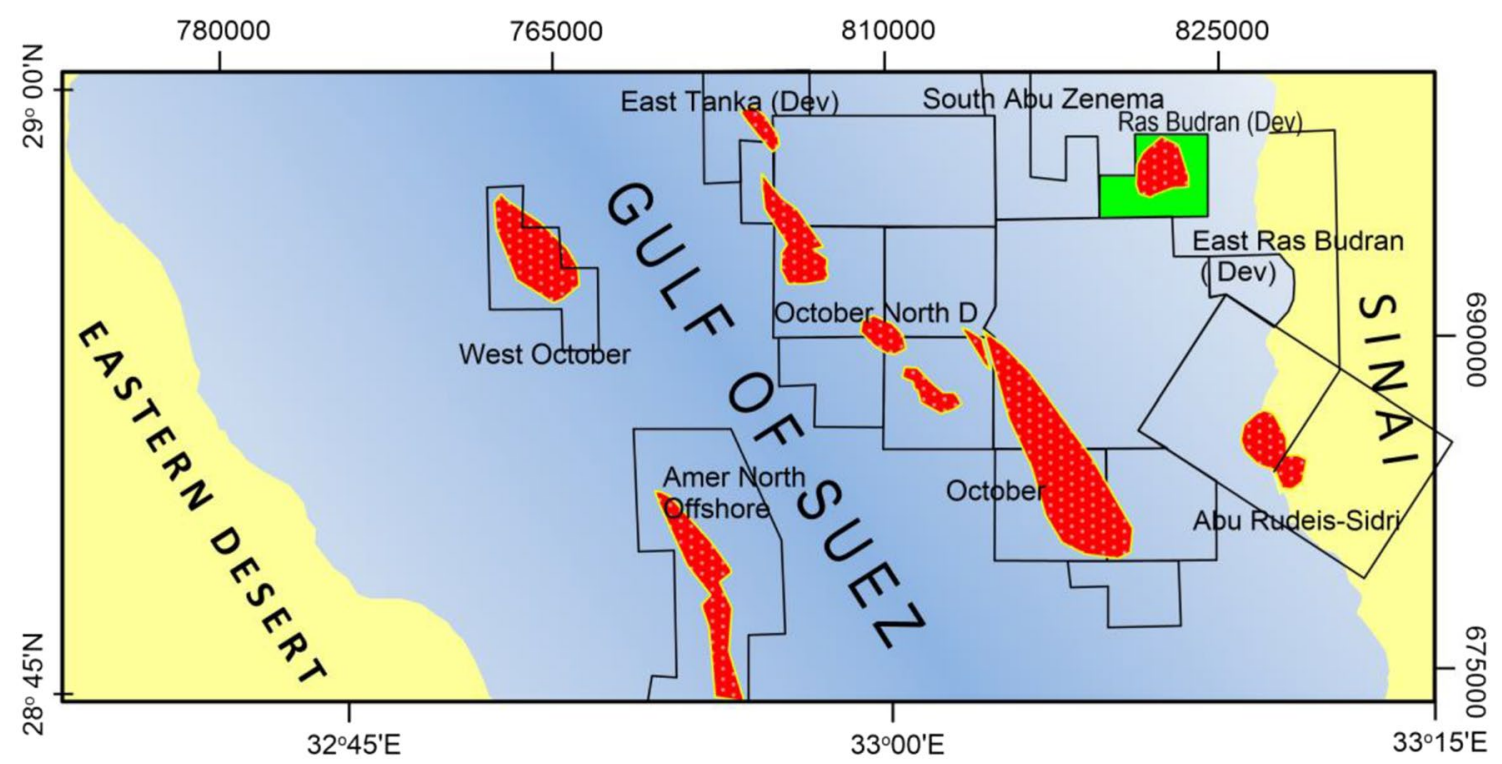

Fig. 1 Location map of the study area showing the major oil fields 
to the anticlinal uplift in the subsurface. This may back to that the filter may distort the phase or amplitude of anomalies when these anomalies fall in the frequency range of the deep sources. In some cases, the thickness and extension of shallow layers in the sedimentary basins are not compatible with the filtering techniques (Azab 2014). Accordingly, the interpretation of the filtered maps mostly fails to spot the fault patterns associated with the block structures. In addition, the depth estimation results show no correlation with the basement depths reached by wells. This makes filtering the gravity anomalies is somewhat ineffective and allows great mistakes in the interpretation. Therefore, the filtered maps are not satisfactory to describe the hidden/deep gravity sources.

Second, we used the strip off technique (Otsuka et al. 1976) which is a preferable method for deep gravity interpretation, since the technique is executed as an explanatory tool to produce a number of gravity maps that are more acceptable and reliable to interpret the deep sources. It simply depends on removing the gravity effects of all rock units above the strip off datum. The gravity effect due to each lithologic rock unit was separately computed, subtracted from the Bouguer gravity data to obtain the gravity signatures caused by the deep constituents.

The exact calculation of the gravity effect of each layer primarily requires enough knowledge about the rock parameters. Accordingly, the available logging data of drilled wells taken from 14 nearby wells were consulted to determine the geometry and density. The top and bottom of each layer were identified from composite well log, and thereafter, an isopach map for each rock unit was done. By isopachs, a rough estimation of the thickness distribution of different sedimentary beds could be made. In addition, the density measurements for each lithologic unit are averaged from RHOB log and are summarized in Table 1. The density/ thickness of each layer was converted into grid with nodes $(46 \times 50)$ which was used in the calculation. With adequate definition of density and geometry of the subsurface strata that overlie the stripping datum, the computing of the gravity effect for each stratum was carried out separately; and was progressively subtracted from the original data to get a meaningful map of deeper structures. The gravity map on basement surface, after removing the effect of the overlying sedimentary cover, enables the identification of the deepseated structures control the area. Several stages for deep gravity interpretation using the gravity stripping were performed at various stratigraphic levels, which yields improved gravity fields on tops of that formations. To confirm the subsurface configurations, the forward modeling technique was applied on two gravity profiles. These two density models were constructed constrained by wells data as inputs. Hence, the outputs became more reliable in defining the structural features as well as the main faults which have affected the basement surface and the overlying pre-Miocene rocks.
Table 1 Density measurements of different drilled wells in the study area

\begin{tabular}{|c|c|c|c|c|c|c|c|}
\hline \multirow[t]{2}{*}{ Formation } & \multicolumn{7}{|c|}{ Density in $\left(\mathrm{g} / \mathrm{cm}^{3}\right)$} \\
\hline & $\begin{array}{l}\text { EE } 85-2 \\
\text { Well }\end{array}$ & $\begin{array}{l}\text { RB-A1 } \\
\text { Well }\end{array}$ & $\begin{array}{l}\text { RB-B3 } \\
\text { Well }\end{array}$ & $\begin{array}{l}\text { RB-C1A } \\
\text { Well }\end{array}$ & $\begin{array}{l}\text { RB-C1 } \\
\text { Well }\end{array}$ & $\begin{array}{l}\text { RB-B8b } \\
\text { Well }\end{array}$ & $\begin{array}{l}\text { RB-B1 } \\
\text { Well }\end{array}$ \\
\hline Post-Zeit & & 2.02 & & & 2.03 & & 2.02 \\
\hline Zeit & & 2.43 & & & 2.4 & & 2.36 \\
\hline S gharib & & 2.63 & & & 2.58 & & 2.5 \\
\hline Belayim & & 2.75 & & & 2.73 & & 2.72 \\
\hline Kareem & & 2.51 & & & 2.44 & & 2.39 \\
\hline Rudeis & & 2.35 & & 2.58 & & 2.41 & 2.36 \\
\hline Nukhul & & 2.52 & & 2.61 & 2.39 & 2.5 & \\
\hline Thebes & & 2.497 & 2.51 & 2.62 & 2.46 & 2.58 & 2.46 \\
\hline Esna.shale & 2.46 & 2.55 & 2.52 & & 2.55 & & 2.49 \\
\hline Sudr & 2.52 & 2.48 & 2.6 & & & & 2.5 \\
\hline Brown limestone & 2.49 & 2.5 & 2.65 & & & & 2.45 \\
\hline Matullah & 2.31 & 2.51 & 2.54 & 2.65 & & & 2.43 \\
\hline Watta & 2.35 & 2.5 & 2.62 & & & & 2.53 \\
\hline Abu-qada & & 2.49 & 2.68 & 2.63 & 2.43 & & 2.45 \\
\hline Raha & & 2.46 & 2.72 & 2.61 & 2.22 & & 2.46 \\
\hline Nubian & 2.31 & 2.34 & 2.59 & 2.37 & 2.32 & 2.46 & 2.39 \\
\hline Paleozoic sand & 2.59 & 2.49 & 2.51 & 2.48 & 2.43 & 2.47 & 2.41 \\
\hline Basement & & & & 2.54 & & & \\
\hline
\end{tabular}




\section{Structural-tectonic setting}

Ras Budran oil field locates on and forms the crest of an $\mathrm{NE}-\mathrm{SW}$ trending platform, aligned at right angles to the Gulf of Suez main trend. The previous literatures indicate that the structure is broken into several parallel panels by a set of NW-SE Clysmic faults. The structural configuration of Ras Budran at Miocene levels reveals an NE-trending feature forming a structural closure. Most these faults are present at pre-Miocene levels, within the Lower Rudeis Formation and near top of Kareem (Chowdhary and Taha 1987). Several stratigraphic and structural studies were carried out on the study area (Abd El Gawad 1970; Zahran 1981, 1986; Khalil 1984; Naggar and Helaly 1985; Bosworth et al. 1998; Younes 2005; Albay 2012; Abu Al-Atta et al. 2014; Atia et al. 2015; ... and others).

Structurally, the pre-Miocene of Ras Budran is very complicated, because it is disturbed by sever faulting at different stratigraphic levels. These faults vanish upward at the top of Thebes and top of Lower Rudeis Formation. In general, the structural complexity is enhanced through two major tectonic phases (unconformities) within the Oligocene and intra-Rudeis (Chowdhary and Taha 1987).

Ras Budran is limited to the northeast by a set of synthetic faults aligned northwest-southeast. These faults with a throw in opposite direction to coastal marginal fault system create a northwest-aligned graben to the northeast of the structure. To the southeast, the structure is bounded by a graben feature in which EE 85-2 well was drilled, while to the northwest, the structure is bounded by a narrow fault zone aligned northeast-southwest. Accordingly, three main blocks are delineated: the northern main block with RB-A1, RB-A5, and RB-A4 wells; the intermediate block with RB-B1 and RB-B4 wells; and the southern smallest block RB-C1 well. Commonly, many previous literatures concern with the geology of the Gulf of Suez including the study area (Abdallah et al. 1963; Hagras 1976; Kulke 1982; Krebs et al. 1996). Figure 2 shows the generalized lithostratigraphic column of the Gulf of Suez (HIS 2006).

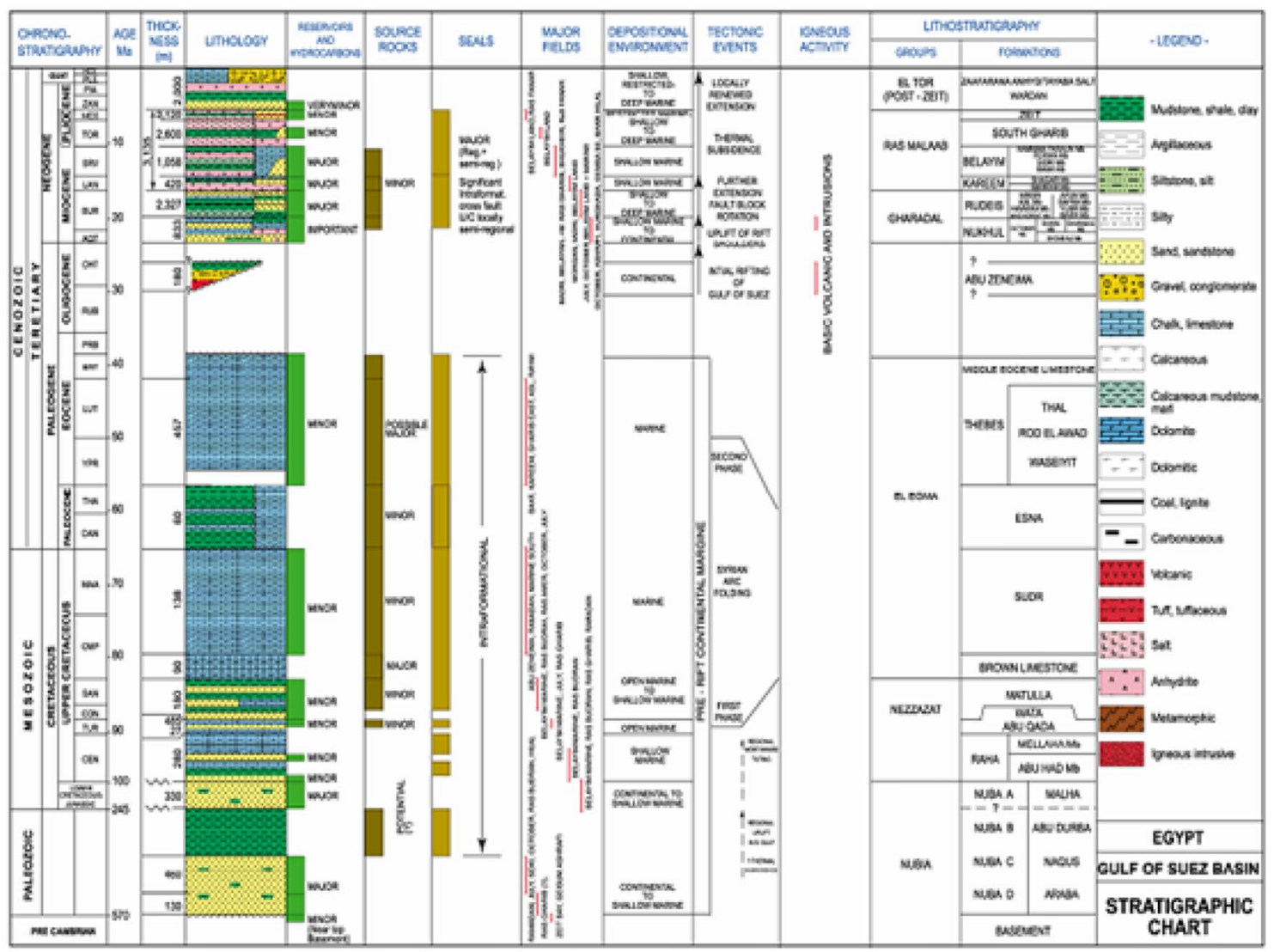

Fig. 2 Generalized lithostratigraphic column of the Gulf of Suez (HIS 2006) 


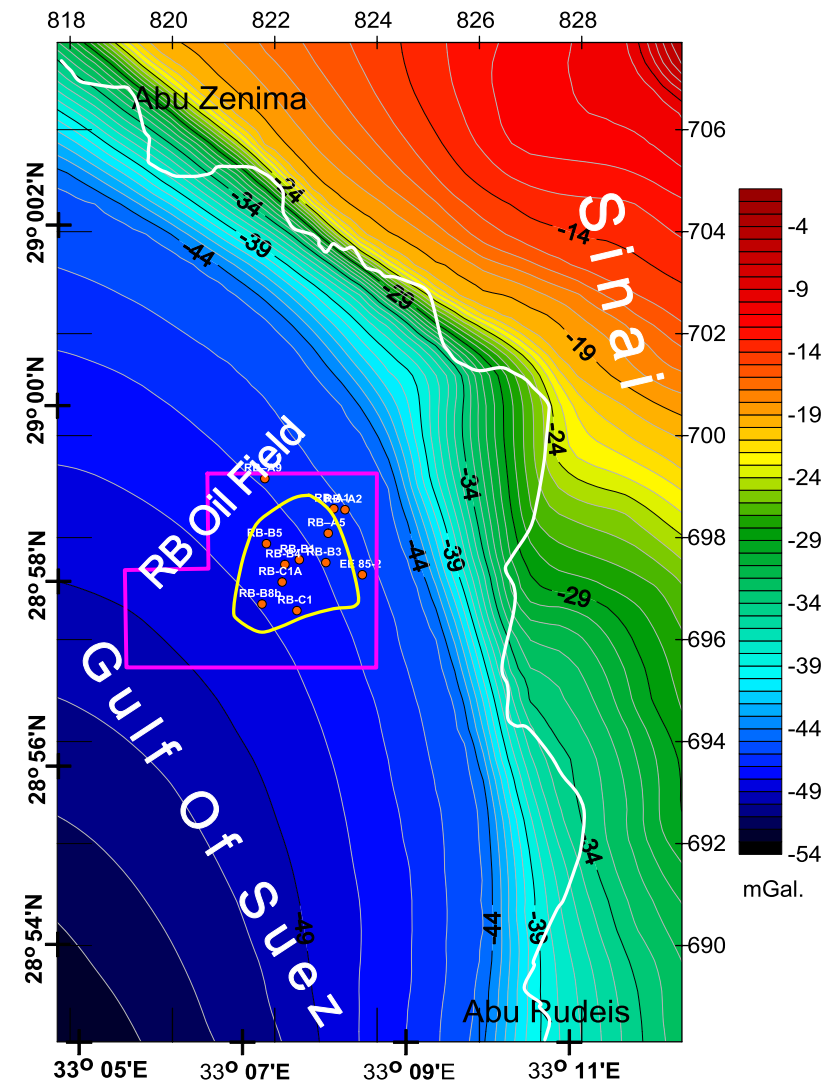

a

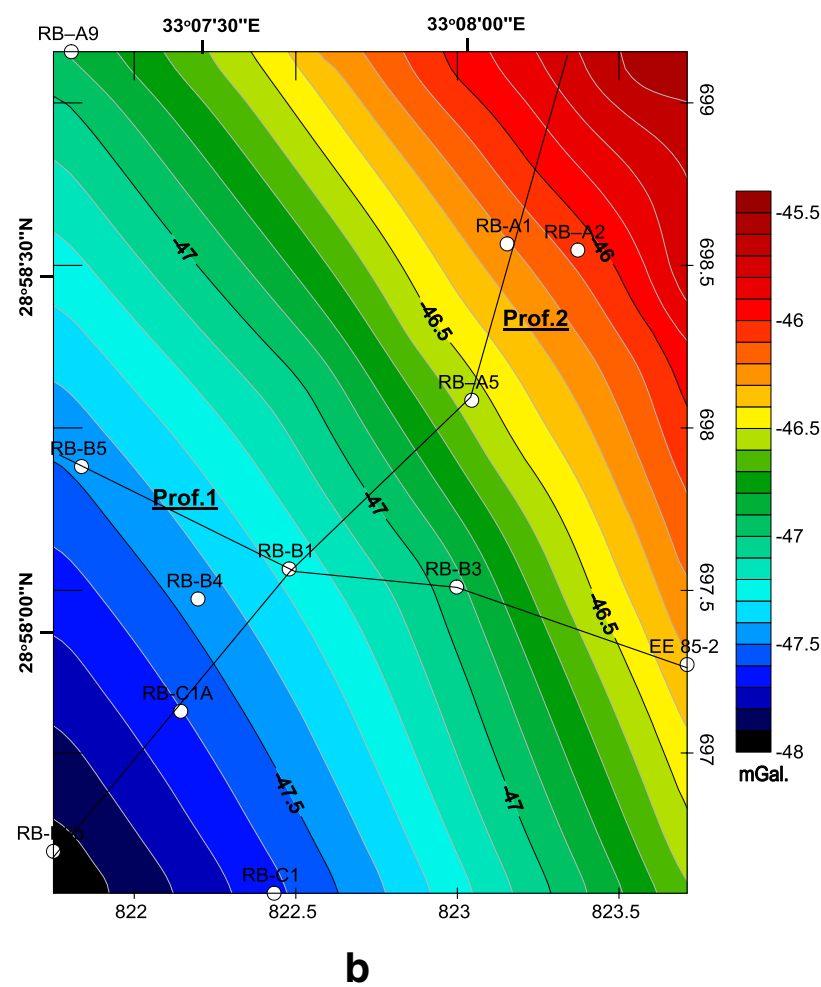

Fig. 3 a Bouguer gravity anomaly map of the study area. b Bouguer gravity anomaly map of Ras Budran oil field showing locations of the drilled wells and modeled profiles

\section{Bouguer gravity map}

Qualitative interpretation of the Bouguer gravity map (Fig. 3a) shows that the gravity field is very complicated by different anomalous features. It is characterized by highand low-gravity anomalies which may reflect great depth variations to its sources and/or large density contrast in the subsurface. In addition, the complex gravity field on the Bouguer map is expected to be associated with great structural variations and major tectonic events. Westward, the map shows that the Gulf of Suez basin is correlated with a noticeable gravity decrease toward the rift axis. Focus on location of the RB-oil field (Fig. 3b) reveals that the concession is characterized by smooth contour lines with gravity decrease toward the southwest. The gravity field does not show any anomalous feature associated with the anticlinal uplift that might be in the subsurface, as suspected based on drilling data. The negative gravity values range between -45 and $-47 \mathrm{mGal}$, suggesting a thick sedimentary cover. The gravity low is bounded from the east by a linear structure along the shoreline. The steep gradient is mostly correlated with a major block-fault zone of a great throw and runs parallel or subparallel to the coast of the gulf. Eastward, the map is characterized by an NW-SE trending anomaly of high magnitude. Such gravity highs are almost attributed to the uplifted basement blocks of southern Sinai massif.

Qualitative interpretation of the Bouguer gravity map (Fig. 3a) shows that the gravity field is very complicated by different anomalous features. The map is characterized by high- and low-gravity anomalies which may reflect great depth variations to its sources and/or large density contrast in the subsurface. In addition, it is expected that the complex gravity field on the Bouguer map is associated with great structural variations and major tectonic events. Westward, the map shows that the Gulf of Suez basin is correlated with a noticeable gravity decrease toward the rift axis. Focus on location of the RB-oil field (Fig. 3b) reveals that the concession is characterized by smooth contour lines with gravity decrease toward the southwest. The gravity field does not show any anomalous feature associated with the anticlinal uplift that might be in the subsurface, as suspected based on drilling data. The negative gravity values ranges between -45 and $-47 \mathrm{mGal}$, suggesting a thick sedimentary cover. The gravity low is bounded from the east by a linear structure along the shoreline. The steep gradient is mostly correlated with a major block-fault zone of a great throw toward the west and runs parallel or subparallel to the coast of the gulf. Eastward, the map is characterized by an NW-SE trending anomaly of high magnitude. Such gravity highs are almost attributed to the uplifted basement blocks of southern Sinai massif. 


\section{Filtering techniques}

As a matter of fact, the gravity anomalies result from the sum of all gravity effects in the subsurface (Skeels 1942; Abu El-Ata et al. 1988). The small short wavelength anomalies on the Bouguer gravity map imply near surface shallow origins. Meanwhile, the larger wavelength ones are caused by deeper sources or extensive shallow sources. The gravity signature on Bouguer map indicates that the area is heavily influenced by the regional geology of the Gulf of Suez and Sinai. Therefore, it is necessary to separate the regional background away from the residual anomalies of interest. In this context, two filtering techniques were carried out to enhance the quality of the local gravity anomalies that are associated with RB-oil field. The regional-residual separation technique was first applied on the Bouguer map using simple theoretical equation of nine points (Nettleton 1976). The diameter with a circle of $5 \mathrm{~km}$ is actually suitable, since it covers the areal extent of the object "RB-oil field". The filter tends to emphasize the smaller and shallower geologic features at the expense of the larger and regional ones. However, the residual gravity map (Fig. 4) shows that no anomalous feature could be definitely correlated with the RB-oil field.

A more elaborate method "second vertical derivative" was applied (Rosenbach 1953) to resolve the gravity data

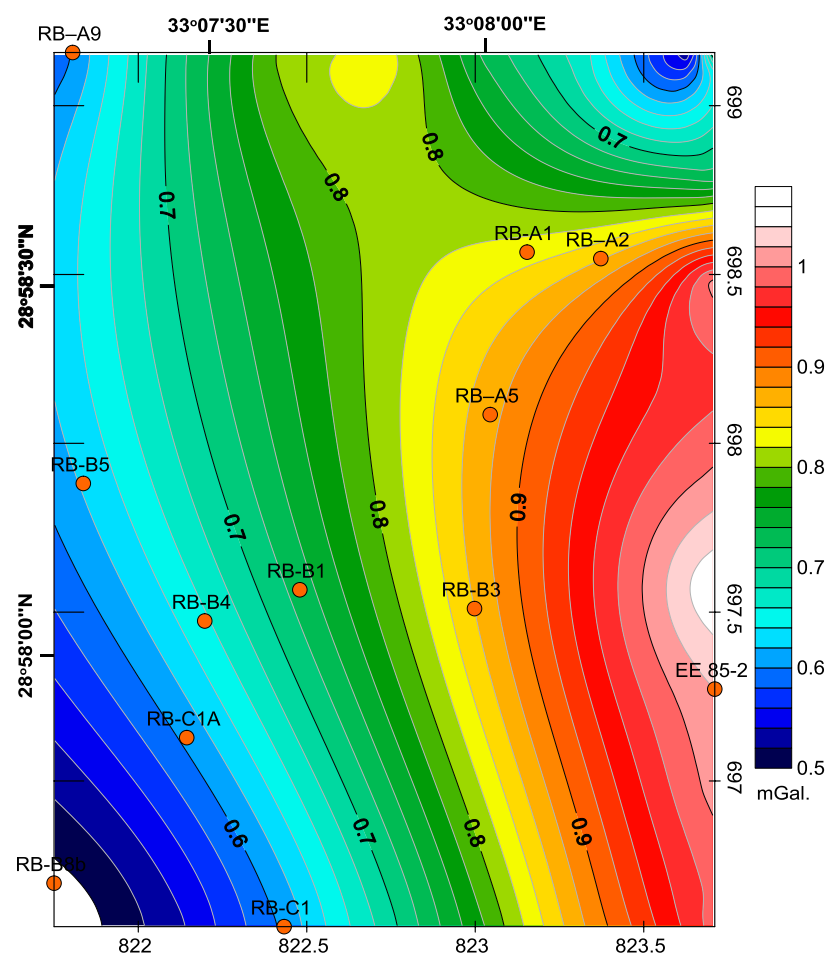

Fig. 4 Residual anomaly map of the Bouguer gravity data

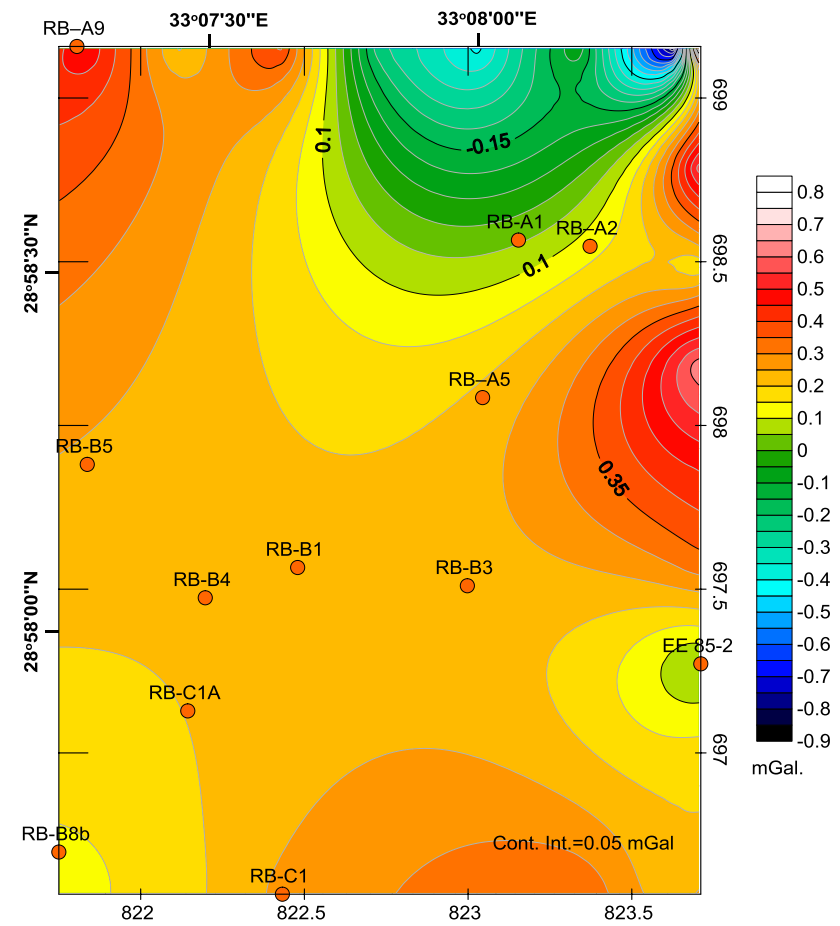

Fig. 5 Second vertical derivative map of the Bouguer gravity data

through the successive differentiation of the Bouguer anomalies with respect to depth. The filter helps to locate anomalies that are difficult to observe on the Bouguer map due to steepness of the regional gradients. To a great extent, the second vertical derivative map (Fig. 5) is consistent with the previously filtered residual map (Fig. 4), since there is no positive anomaly matched with the uplift. The same results obtained from the two methods may give credibility to both two techniques.

Qualitatively, both the residual map (Fig. 4) and second vertical derivative map (Fig. 5) still show up with the distribution the same general structural conclusions that have been obtained from the Bouguer map. The structural interpretation is difficult, because the gravity anomalies correlated with the RB-oil field are very small in amplitude and short wavelength. They may approximate errors caused by the lithologic variation in the subsurface. Both these two filtered maps are incapable of exact solution because of the inherent ambiguity in defining the deep source of the gravity field. Thus, the filtering process not acts well in eliminating the ambiguity in the gravity field, but it is an effective tool in removing the regional trend. 


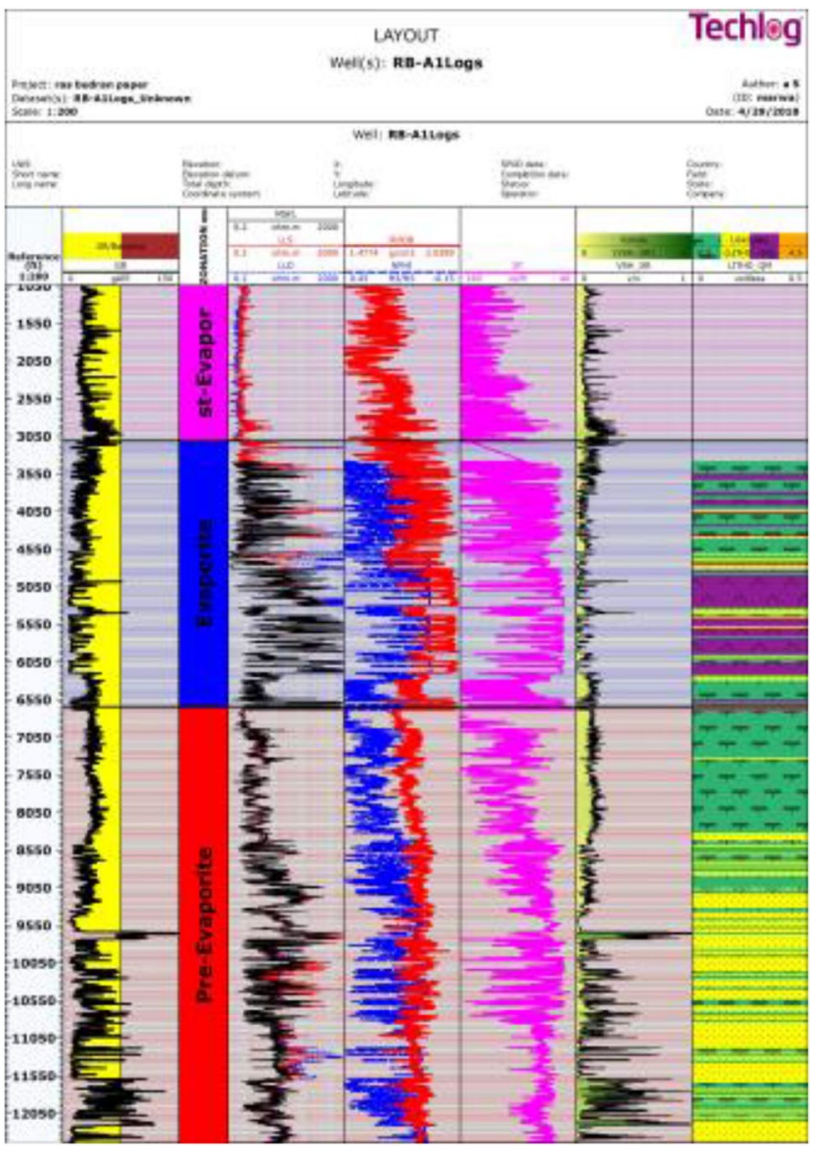

Fig. 6 Litho-saturation cross plot of RB-A1 well

\section{Litho-saturation cross plot}

The stratigraphic units in Ras Budran oil field range in age from Precambrian to recent (Chowdhary and Taha 1987). The available data (GR, DT, Nphi, RHOB, LLD, and LLM) of RB-A1 well, drilled in the northern part of the study area has been interpreted as a stratigraphic sequence (Fig. 6). Three main phases have been shown in the geologic section of this region: the first one ranging in age from Paleozoic to Eocene and interval from 12,170 to $8675 \mathrm{ft}$. It is lithologically consists mainly of sandstone intercalated with thin beds of shale. The pre-Miocene interval represents that Nubia (A and B), Raha, Matulla, Watt, Sudr, and Thebes formations are considered as reservoir rock units in the study area, while Paleozoic Nubia (C and D) acts as source rock. The second phase is represented by Early Miocene which ranges in depth from 8675 to $6650 \mathrm{ft}$, containing Nukhul, lower Rudeis and Upper Rudeis formations. The interval is lithologically characterized by sandy shale which acts as a source rock and sometimes considered as reservoir rock. The third phase of Middle-Late Miocene age consists of evaporite group (Kareem, Belayim, South Gharib, and Zeit formations). It acts essentially as a cap rock or seal of the oil accumulation with no importance as source or reservoir (Hassouba et al. 1994; Zein El-Din et al. 1995; Zein El-Din et al. 1997). The sandstone intervals of Thebes, Raha, and Nubia (A and B) formations represent the most important reservoir intervals. Meanwhile, the evaporate group is the most significant cap rock in Ras Budran oil field.

\section{Density-depth relationship}

The gravity effect is very sensitive to density contrast among different rock units, which significantly affect the results. Therefore, to calculate and remove the effect of the sedimentary succession from the gravity data, it must carefully determine the density of various layers above the datum. Figure 7a shows the density against depth as measured in RB A-1 and RB B-1 wells. It is evident that the distribution of the formation density shows a great similarity for both two wells. The plot shows that the density does not linearly correlate with depth, but varies with the lithology. The upper sequence (post-Zeit) has the lowest density values $(\sim 2 \mathrm{~g} /$ $\mathrm{cm}^{3}$ at $2000 \mathrm{ft}$ ), as determined at RB A-1 well. The density of evaporites that exist in Kareem, Belayim, South Gharib, and Zeit formations is very variable according to lithology (facies change to clastics). The evaporite rocks consists mainly of anhydrite (high density is about $>2.85 \mathrm{~g} / \mathrm{cm}^{3}$ ), salt rocks of low density (about $2.1 \mathrm{~g} / \mathrm{cm}^{3}$ ), and interbeds of sands/shale of medium density (is $\sim 2.4 \mathrm{~g} / \mathrm{cm}^{3}$ ). The density of the evaporite may differ from layer to anther depending on the percentage of these volatiles into the sequence.

Commonly, the evaporite group is characterized by a high density than other rock types in the stratigraphic column. Downward, the density logs of the pre-evaporite group from Paleozoic Nubian to Rudeis formations are available through all drilled wells (Table 1). In general, the densities of preMiocene formations do not vary greatly from each other, with depth. The Nubian rock is lower in density than the Miocene clastics (Nukhul, Rudeis Fms). The average density of the basement is assumed to be $2.56 \mathrm{~g} / \mathrm{cm}^{3}$, which is the equivalent density of the granitic rocks at BR C-1a well (Fig. 7b). The largest density contrast $\left(\sim-0.6 \mathrm{~g} / \mathrm{cm}^{3}\right)$ occurs between evaporite and post-evaporite. Such change in lithology (density contrast) may produce relatively large gravity anomalies which obscure the effect of the deeper structures. Figure 7c shows three density sections divided into separate units in accordance with facies changes. The density contrast with adequate thickness/depth variations (as shown in Table 2) is enough to produce significant gravity effects either positive or negative. Table 2 shows that the distribution of the pre-Miocene formations is greatly different from place to place. It could be noticed that the thickness of the rock units increases in some wells, decreases in others, and disappears in some localities. In addition, the lateral density

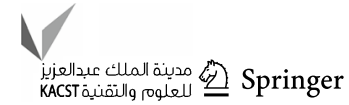




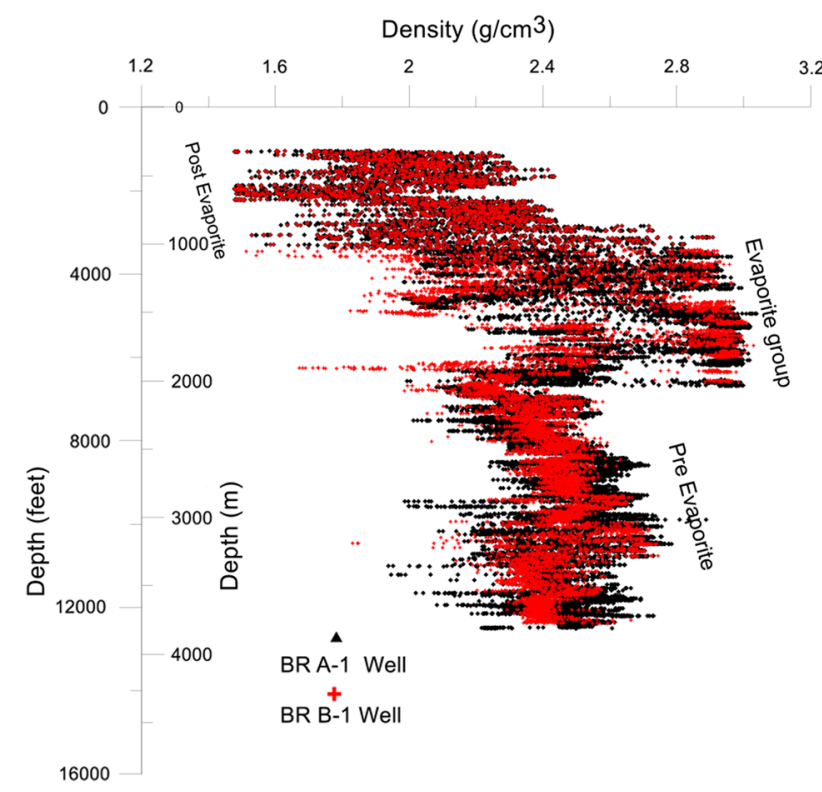

a
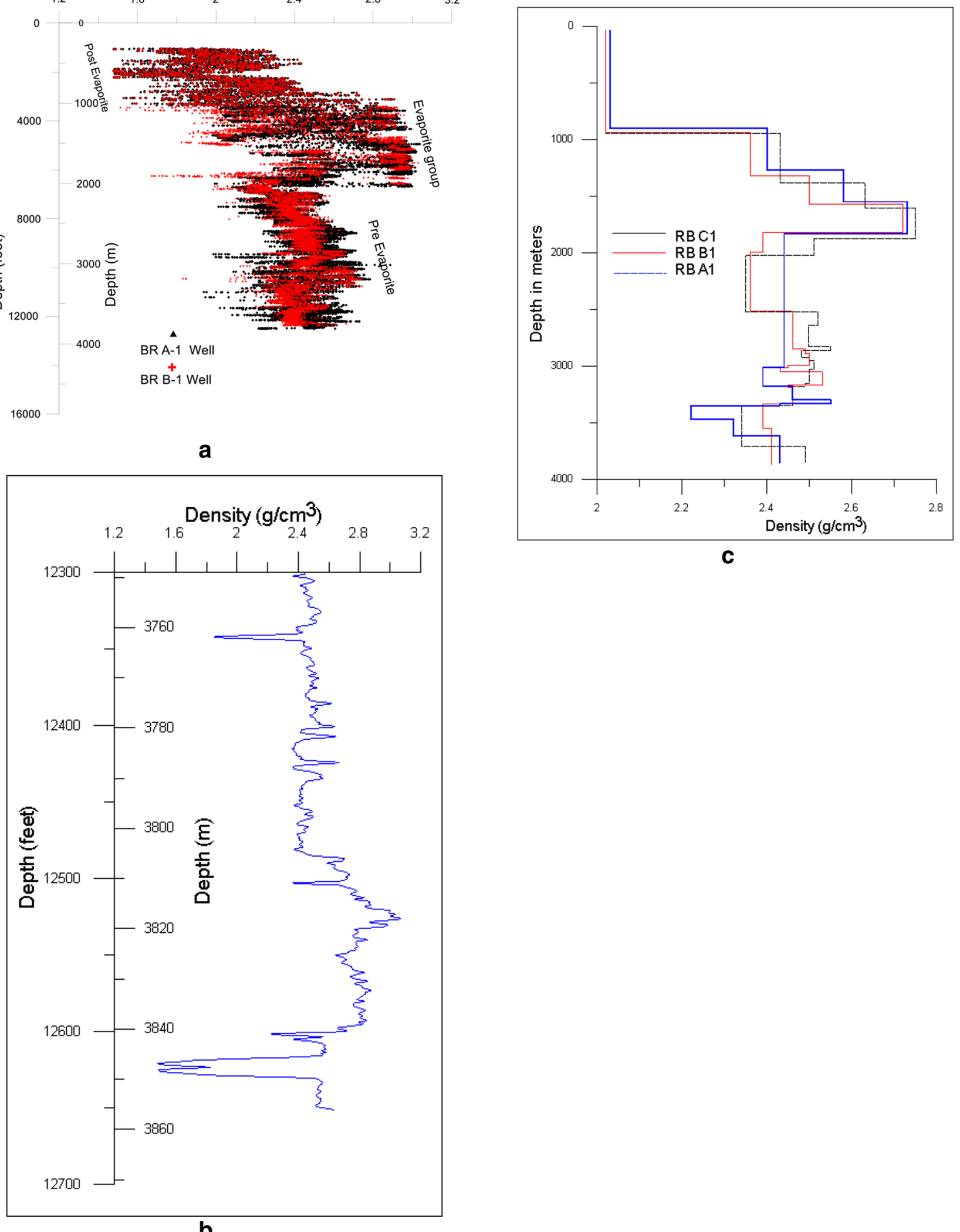

C

\section{b}

Fig. 7 a Vertical distributions of density measurements along wells RB A-1 and RB B-1. b Density $\log$ measurements of the basement rocks in RB C-1A well. c Vertical density distribution along BR A-1, BR B-1, and BR C-1A wells 
Table 2 Thickness of different sedimentary formations in the study area

\begin{tabular}{|c|c|c|c|c|c|c|c|c|c|c|c|c|}
\hline \multirow[t]{2}{*}{ Formations } & \multicolumn{12}{|c|}{ Thickness in $(\mathrm{km})$} \\
\hline & $\begin{array}{l}\text { RB-A9 } \\
\text { well }\end{array}$ & $\begin{array}{l}\text { RB-A1 } \\
\text { well }\end{array}$ & $\begin{array}{l}\text { RB-A2 } \\
\text { well }\end{array}$ & $\begin{array}{l}\text { RB-A5 } \\
\text { well }\end{array}$ & $\begin{array}{l}\text { RB-B5 } \\
\text { well }\end{array}$ & $\begin{array}{l}\text { RB-B1 } \\
\text { well }\end{array}$ & $\begin{array}{l}\text { RB-B3 } \\
\text { well }\end{array}$ & $\begin{array}{l}\text { RB-B4 } \\
\text { well }\end{array}$ & $\begin{array}{l}\text { EE 85-2 } \\
\text { well }\end{array}$ & $\begin{array}{l}\text { RB-C1A } \\
\text { well }\end{array}$ & $\begin{array}{l}\text { RB-B8b } \\
\text { well }\end{array}$ & $\begin{array}{l}\text { RB-C1 } \\
\text { well }\end{array}$ \\
\hline Post-Zeit & 0.9266 & 0.9083 & 0.9065 & 0.9394 & 0.911 & 0.8964 & 0.897 & 0.8955 & 0.8153 & 0.8699 & 0 & 0.8626 \\
\hline Zeit & 0.4526 & 0.4398 & 0.4359 & 0.4337 & 0.4106 & 0.3862 & 0.3926 & 0.3932 & 0.5148 & 0.3691 & 0 & 0.3685 \\
\hline $\mathrm{S}$ gharib & 0.2496 & 0.221 & 0.2225 & 0.2216 & 0.2637 & 0.2502 & 0.2426 & 0.2454 & 0.2429 & 0.2774 & 0 & 0.2816 \\
\hline Belayim & 0.2999 & 0.2688 & 0.2694 & 0.2697 & 0.2624 & 0.2451 & 0.2444 & 0.2463 & 0.2374 & 0.2801 & 0.2716 & 0.2789 \\
\hline Kareem & 0.2304 & 0.1497 & 0.1561 & 0.1308 & 0.2228 & 0.1783 & 0.1731 & 0.175 & 0.2161 & 0.2146 & 0.239 & 0.2027 \\
\hline Rudeis & 1.271 & 0.4971 & 0.4645 & 0.5047 & 0.9833 & 0.5185 & 0.47 & 0.5197 & 0.6888 & 0.9851 & 0.9528 & 0.9815 \\
\hline Nukhul & 0.3136 & 0.1219 & 0.1585 & 0.1106 & 0 & 0 & 0.0107 & 0 & 0.0299 & 0.1183 & 0.0933 & 0.1655 \\
\hline Thebes & 0 & 0.1838 & 0.2761 & 0.1256 & 0 & 0.3331 & 0.4036 & 0.3173 & 0.3627 & 0.0183 & 0.2731 & 0.1207 \\
\hline Esna.shale & 0 & 0.0378 & 0.0381 & 0.0716 & 0 & 0.0439 & 0.0372 & 0.0311 & 0.0433 & 0 & 0 & 0.0107 \\
\hline Sudr & 0 & 0.0582 & 0.0277 & 0 & 0 & 0.0991 & 0.0411 & 0.0896 & 0.0671 & 0 & 0 & 0 \\
\hline Brown limestone & 0 & 0.0299 & 0.0597 & 0.0613 & 0 & 0.0259 & 0.0378 & 0.0607 & 0.0671 & 0 & 0 & 0 \\
\hline Matullah & 0 & 0.0747 & 0.1335 & 0.1015 & 0.1049 & 0.0332 & 0.1167 & 0.1082 & 0.0841 & 0.0445 & 0 & 0 \\
\hline Watta & 0 & 0.1283 & 0.1125 & 0.1283 & 0.096 & 0.1158 & 0.1381 & 0.0762 & 0.029 & 0 & 0 & 0.0238 \\
\hline Abu-qada & 0 & 0.0229 & 0.029 & 0.0241 & 0 & 0.0232 & 0.0198 & 0 & 0.0165 & 0.0265 & 0 & 0.0149 \\
\hline Raha & 0 & 0.171 & 0.2012 & 0.1561 & 0.089 & 0.1457 & 0.0058 & 0.0829 & 0.1134 & 0.1658 & 0 & 0.1189 \\
\hline Nubian & 0.4383 & 0.3587 & 0.2268 & 0.2899 & 0.2228 & 0.2152 & 0.3267 & 0.3481 & 0.1972 & 0.1893 & 0.2874 & 0.1469 \\
\hline Paleozoic sand & 0.06 & 0.1494 & 0 & 0.2877 & 0.142 & 0.3167 & 0.1896 & 0.1942 & 0.3691 & 0.196 & 0.0814 & 0.2371 \\
\hline
\end{tabular}

contrast, with or without thickness variation, could produce gravity anomalies, e.g., due to faulting. Such density variations between different wells for the same rock unit could be noticed well in Table 1.

\section{Stripping technique}

The interpretation takes an alternative way through applying the stripping technique to reach a degree of consistency for the deep-seated structures. The method of Otsuka et al. 1976 is the most suitable for doing such deep investigations. The technique is simply to compute the gravity effect of various rock units, whose density and geometry are known, followed by the subtraction of these effects from the observed gravity (Otsuka and Ogawa 1977). Hence, the resultant data allow to map the regional anomalies and consequently more knowledge of the deep-seated constituents.

The lower limit of the stripped zone is the top of the basement, which was overlain by 17 lithologic units (Table 1). The stripping of each layer in the sedimentary cover was built up based on the density contrast between the body/formation and the basement rocks. The density of each stratum gives gravity differences (density contrast) referred to the "basement rocks" which has zero effect. The topographic (thickness) variations were also defined from the composite well logs and the isopach maps. The gravity contributions of the different lithologic packages (post-evaporite, evaporite, and pre-evaporite) are summarized in Fig. 8a, b, c. Figure 8d shows the sum of the gravity effects on top of the basement surface.

Figure 8a shows the gravity effect due to the surficial layers of post-evaporite/post-Zeit sequence which is strong enough and superior. The map is characterized by large negative gravity effect due a gap of density contrast of about $-0.6 \mathrm{~g} / \mathrm{cm}^{3}$ as well as a huge thickness. The average gravity effect of this contribution is of the order of $-22 \mathrm{mGal}$ (about $45 \%$ of the observed gravity). The striped values decrease toward the northwestern corner, attains a minimum ( $-21 \mathrm{mGal})$ around RB A-5 well, and reaches a maximum ( $-18 \mathrm{mGal})$ at EE85-2 well. The narrow range of milligals may be associated with slight variation in thickness of the surface layer.

Figure $8 \mathrm{~b}$ displays the sum of gravity effects due to the evaporite group (Kareem, Belayim, South Gharib, and Zeit). This sequence exerts a positive effect on the observed gravity field because of the high density of the anhydrite (Belayim) rocks. The gravity effect of these rock units seems to be in opposite direction to the former one (Fig. 8a). It decreases gradually from northeast to southwest, where the contour values range from $-2 \mathrm{mGal}$ at $\mathrm{RB} \mathrm{B}-1$ well to about $1 \mathrm{mGal}$ at RB-A 1 well. The data derived from the drilled wells indicate that the evaporite rocks are generally deposited in a large thickness throughout the study area and increases in the northeast direction. The positive gravity effect of the evaporites seriously distorts the effect of the underlying clastic rocks.

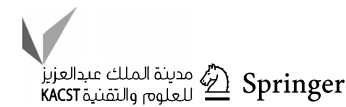



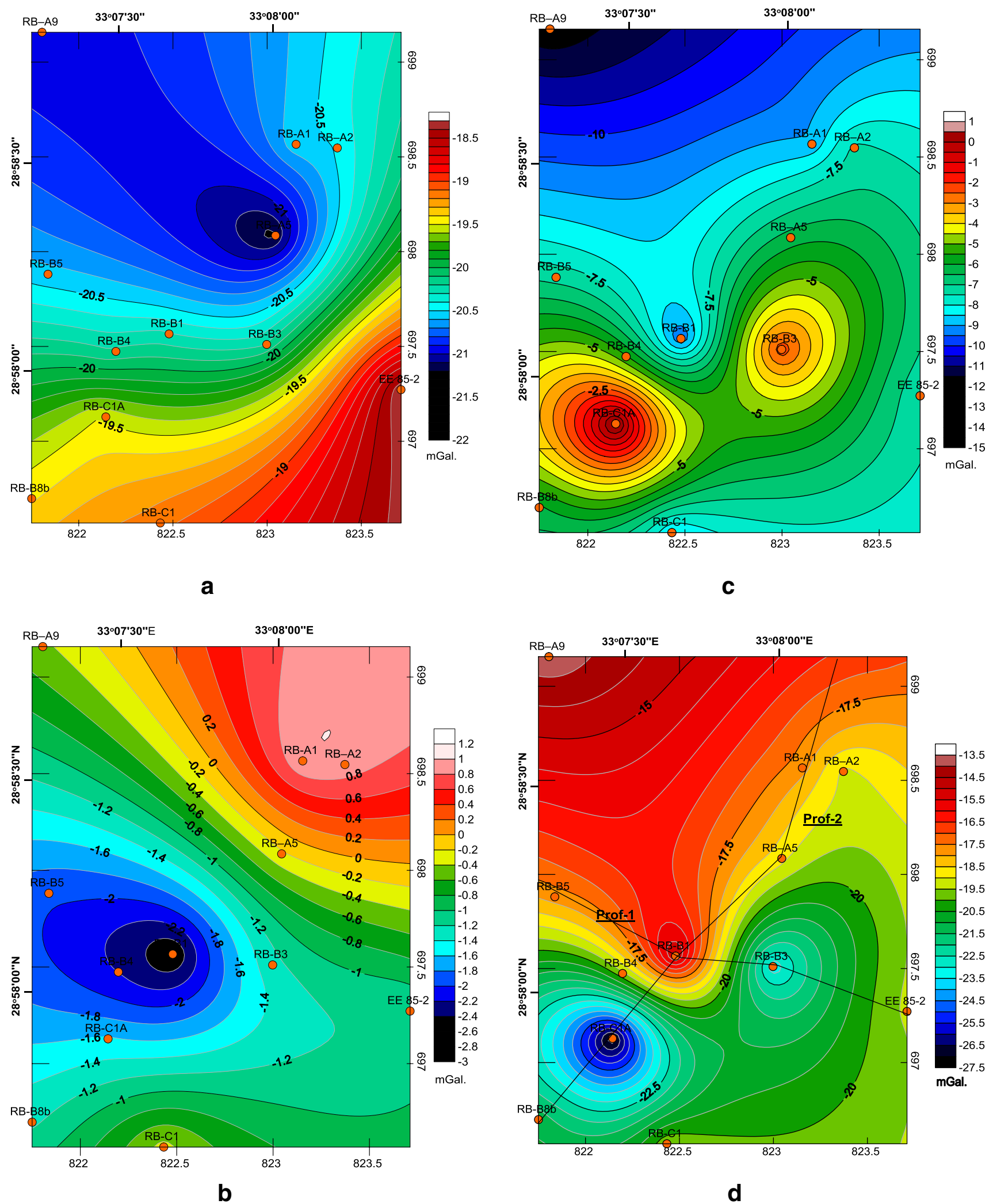

Fig. 8 a Gravity effect of post-evaporite rocks. b Gravity effect of evaporite rocks. c Gravity effect of pre-evaporite rocks. d Gravity effect on basement surface 
Figure $8 \mathrm{c}$ shows the gravity effect of the pre-evaporite strata, from Paleozoic Nubian to Rudies sands. The gravity effect of this contribution creates two local anomalous features around RB B-3 and RB C-1a wells. These two local gravity lows denote locations of two depositional areas, where the sediments are preserved in low-lying blocks. Such local thickening may increase the possibility of the source rocks or reservoirs for oil prospecting. Commonly, the map shows a negative gravity effect ranges from 1 to $-15 \mathrm{mGal}$ which reflects a great variation in thickness of the clastic rocks from north to south. The strong effect of this sequence generates the most relevant contribution to gravity, particularly in the southern portion.

Figure 8d shows the residual gravity effect on the basement surface after removing the effect of the overlying sedimentary cover. It represents a key-interpretive map for identifying the deep-seated structural features. The stripped gravity map allowed the identification of two low topographic areas to the south of RB-oil field. They outline location of two deep basins, where the pre-Miocene rocks were preserved in the down thrown blocks of the major faults. The amplitudes of the stripped anomalies are expected to be closely related to depths of these depocentres.

\section{Modeling}

The gravity interpretation was enhanced through using the 2.5-D forward modeling technique. The information drawn from gravity modeling is extremely helpful in delineating deep prospects below the base of the evaporite section when combined with drilling and seismic data (Meshref and Hammouda 1982; Azab 2014). The structure of the RB-oil field is illustrated by two sections aligned in the NE and NW directions. The GM-sys included in the Oasis montage package (6.4.2) was used to construct these two models focusing on the uppermost $5 \mathrm{~km}$ of the crust. They were constrained by well-logging information and outputs obtained from the gravity stripping. The average density and geometry of the sedimentary layers are assigned in accordance with data in Tables 1 and 2.

The first model (Fig. 9a) exhibits a fault-bounded high block in the central area surrounded by two low topographic areas to the east and west. The pre-Miocene anticlinal uplift is broken into several blocks by a set of step faults that throw in opposite directions. The model shows that the pre-Miocene structure is complex and this complexity is not reflected at shallower levels. All faults are present at pre-Miocene levels and finish within Lower Miocene Rudeis Formation. To the east, the uplifted structure is bounded by a halfgraben feature in which the EE85-2 well was drilled. The pre-Miocene strata from Nubia to Thebes are deposited in a uniform thickness of about $5000 \mathrm{ft}$. Post-Rudeis sediments,

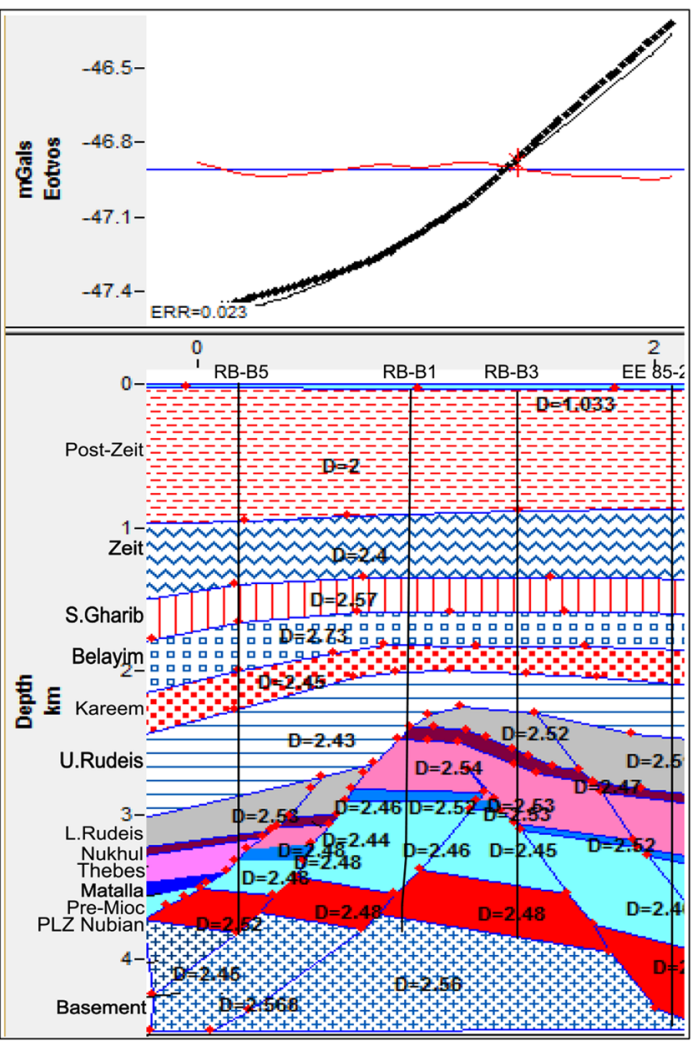

a

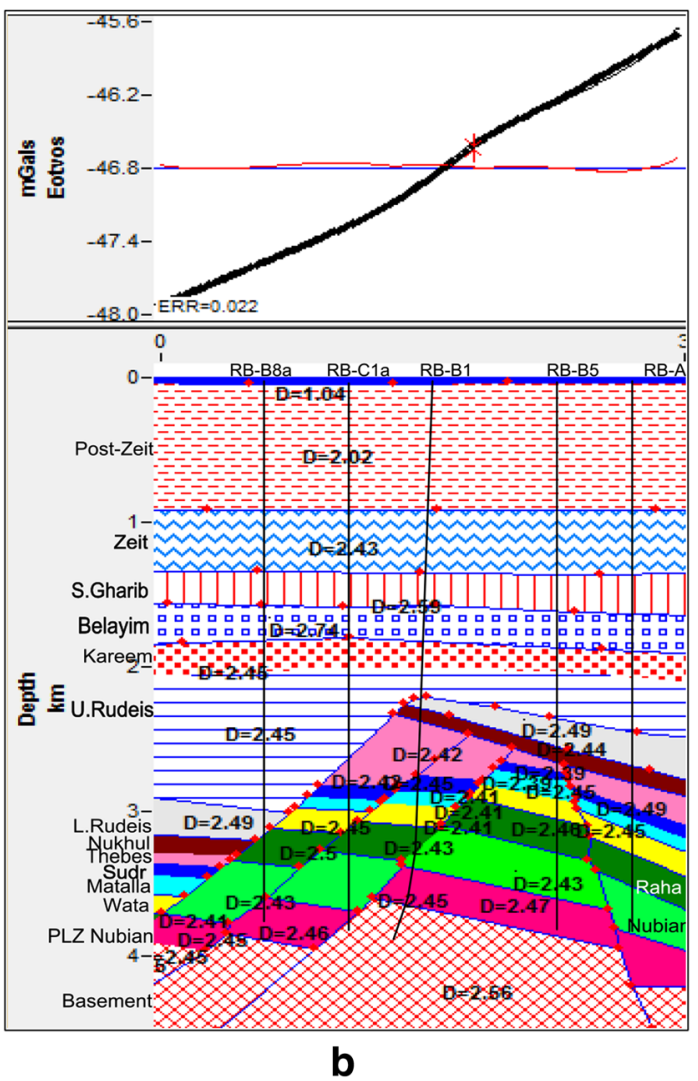

Fig. 9 a 2.5 Density model along prof-1 in the NW-SE direction. b 2.5 Density model along prof- 2 in the SW-NE direction 
evaporite group, and post-Zeit rocks were also distributed in a uniform thickness all over the area. The Rudeis Formation seems to be fully preserved in the downthrown blocks of the major faults. Commonly, the gravity model shows that there is no correlation between the observed gravity and basement surface.

Figure $9 \mathrm{~b}$ shows that the RB-oil field lies on a broad platform, flanked to the south by a synclinal depression. The pre-Miocene structure is bounded by a major fault of large throw and down stepping to the south. The model indicates that the lower part of stratigraphic units is more complicated if compared with the upper portion of Miocene recent. The deeper rock units are severely disturbed and fractured by faults that are present at different pre-Miocene levels and die out within Rudeis Formation. The pre-Miocene clastics are fully preserved in regular sequence into the down thrown blocks of these major faults. The structure shows obvious thickening of the Rudeis formation in these topographic lows, as a result of intense phase of tectonism and erosion occurred during intra-Rudeis. The uppermost layers of the evaporite/ post-evaporite rocks are uninterrupted and nearly uniform in thicknesses.

\section{Conclusion}

The gravity effects of the lithological rock units are varying in values and signs as deduced from the stripping off results. It is found that the gravity effect on the basement surface is of the order of $-18 \mathrm{mGal}$; meanwhile, the gravity effect of the overlying sedimentary section is about $-29 \mathrm{mGal}$, subdivided as: the surface layer is $-22 \mathrm{mGal}$, evaporites is about $0.5 \mathrm{mGal}$, and pre-Miocene is $-7 \mathrm{mGal}$. This implies that the shallow sources, especially post-Zeit rocks, are the main source of most gravity anomaly in the study area. The stripping off results contradict the idea that the major gravity effect is related to the deep-basement sources.

Removing the gravity effect is very effective, since it led to significant modification with respect to the gravity signature on the Bouguer map. The strip off results at the pre-Miocene level exhibit two gravity minima which was interpreted to be the expression of two sedimentary piles.

The models exhibit an anticlinal trap broken into several blocks by a system of faults stepping down to the south and southwest. Such a pre-Miocene uplift provides a structural and stratigraphic focal point for oil accumulation. The step faulting complicates the structure on the basement surface, creating half-graben features in which EE 85-2 and BR C-1 wells were drilled.

From our point of view, the drilled wells in the study area may need reassessment. Extra efforts must be pinpointed into the southern portion. The exploration potential in the southern part is better than that in the northern, where the thick Rudeis sands and pre-Miocene clastics are the main targets. The topography in this potion is not clear enough due to lack of well data.

From our point of view, the drilling in the study area may need reassessment. Extra efforts must be exerted in the southern portion, where the exploration potential in this portion is better than that in the northern part. The thick Rudeis sands and pre-Miocene clastics are considered as the main targets. The deep topography in this part is not clear enough due to lack of well data.

Acknowledgements The author would like to thank Dr. Abu El Ata, prof. of Geophysics, Ain Shams University, Cairo, for his revision of this work.

Open Access This article is distributed under the terms of the Creative Commons Attribution 4.0 International License (http://creativeco mmons.org/licenses/by/4.0/), which permits unrestricted use, distribution, and reproduction in any medium, provided you give appropriate credit to the original author(s) and the source, provide a link to the Creative Commons license, and indicate if changes were made.

\section{References}

Abd El Gawad M (1970) The Gulf of Suez; A brief review of stratigraphy and structure. Rev Phil Trans Roy Soc Lond A 267:41-48

Abdallah AM, Adindani A, Fahmy N (1963) Stratigraphy of the lower mesozoic rocks, western side of the Gulf of Suez. Rev Geol Surv Mining Resour Dept 27:1-23

Abu El-Ata, ASA (1988) The Relation between the local tectonics of egypt and the plate tectonics of the surrounding regions, using geophysical and geological data. In: E.G.S. proceeding of the 6th Annual Meeting, pp. 92-112

Abu Al-Atta M, Issa IG, Ahmed AM, Afife MM (2014) Source rock evaluation and organic geochemistry of belayim marine oilfield, Gulf of Suez, Egypt. Egypt J Pet (Egypt), 23(3):285-302 (Review of Accepted: 18 September 2013)

Albay MA (2012) Geological studies and hydrocarbon potentialities of the cenomanian Raha Formation, Ras Budran Field, Gulf of Suez, Egypt. Msc. Thesis, Menufia University

Atia MH, Ahmed AM, Korrat I (2015) Thermal maturation simulation and hydrocarbon generation of the turonian wata formation in ras budran oil field, Gulf of Suez, Egypt. Rev J Environ Sci, 44(1):57-92

Azab AA (2014) Agnes high, western desert, Egypt: a structuralstudy in view of potential data modeling. Egypt J Pet 2014 23:229-245

Bosworth W, Crevello RD, Winn JR, Steinmetz J (1998) Structure, sedimentation, basin dynamics during rifting of the Gulf of Suez and northwestern Red Sea. In: Purser HB, Bosence JWD (eds) Sedimentation and tectonics of rift basins: Red Sea-Gulf of Aden (77-96). Chapman and Hall, London

Chowdhary LRS, Taha MA (1987) Geology and habitat of oil in Ras Budran field, Gulf of Suez. Rev Am Assoc Pet Geol Bull 71:1274-1293

Hagras MA (1976) In the distribution and nature of the Miocene sediments in the Gulf of Suez (pp. 12). 5th Egyptian General Petroleum Corporation Exploration Seminar, Cairo

HIS E (2006) Gulf of Suez Basin Monitor (No. Iris21 ID:410900. IHS Energy) 
Khalil B (1984) Geological and sedimentological studies of Oligocene-Miocene section in Abu Zenima and October field, Sinai, Egypt. Ain Shams University

Krebs WN, Wescott AW, Nummedahl D, Gaafar I, Azazi G, Karamat AS (1996) Graphic correlation and sequence stratigraphy of Neogene rocks in the Gulf of Suez. In: Youssef MI (ed.) Proceedings of the 13th Petroleum Conference (214-226), Egyptian General Petroleum Corporation, Cairo

Kulke H (1982) In Miocene carbonate and anhydrite sequence in the Gulf of Suez as a complex oil reservoir (pp. 269-275). Paper presented at the 6th exploration and production conference, egyptian general petroleum corporation, Cairo

Meshref W, Hammouda H (1982) Stripping techniques in sea floor gravity interpretation of the south Belayim area, Gulf of Suez. In: 6th EGPC Exploration Seminar, Cairo

Moon FW, Sadek H (1923) Preliminary geological report on Gebel Khoshera area (West Sinai). Rev Pet Res Bull 9:40 (Government Press)

Naggar AA, Helaly A (1985) Ras budran field: geological aspects and reservoir units. In: 8th EGPC production seminar, March, 1985, Cairo

Nettleton LL (1976) Gravity and magnetic in oil exploration. Mc. Graw Hill Publication Co., New York

Otsuka T, Ogawa K (1977) Combined seismic and gravity interpretation in west Bakr area, Gulf of Suez, Egypt. Report of Technology Research center. JPC, Tokyo, 6
Otsuka T, Ogawa K, Takasu Y (1976) Combined seismic and gravity interpretation in west Bakr area, Gulf of Suez, Egypt. 5th Exploration Seminar, EGPC Cairo

Rosenbach O (1953) A contribution to the computation of the "second derivative" from gravity data. Geophysics 18(4):894-912

Skeels DC (1942) The value of quantitative interpretation of gravity data. Geophysics 7:345-353

Younes AM (2005) Modelling petroleum generation and geochemistry of crude oils in Ras Budran Field, Northern Gulf of Suez, Egypt: implications for prospectively. Review. Oil gas european, OG 194-OG 200

Zahran M (1981) The geology of west Abu Rudeis; October oil field; with reference to the geology of the Gulf of Suez. Faculty of Science, Cairo University

Zahran M (1986) In Geology of October field. The 8th exploration international conference, Egyptian General Petroleum Cooperation, Cairo

Publisher's Note Springer Nature remains neutral with regard to jurisdictional claims in published maps and institutional affiliations. 